\title{
Uso de papaína na cicatrização de ferida em um equino
}

Anna Christina Schmitz

*Autor correspondente

e-mail: anna.schmitz88@hotmail.com

\section{Resumo}

Os cavalos são constantemente acometidos por feridas, pois em seu habitat natural são presas e estão sempre prontos para fugir diante de ameaças. Este comportamento natural dos equinos os tornam animais propensos a ferimentos, principalmente na região distal dos membros. Estas feridas são consideradas de difícil cicatrização por conta dos movimentos das articulações, má circulação, espessura mínima dos tecidos moles e também por haver maior risco de contaminação devido a sua proximidade com o solo. A papaína, proveniente do látex do mamoeiro Carica papaya, pode ser uma alternativa para o tratamento de feridas. Ela é uma proteína que contém enzimas proteolíticas e peroxidases que degradam proteínas em aminoácidos do tecido desvitalizado e da necrose, sem alterar o tecido sadio, isso devido à ausência de uma antiprotease plasmática, a $\alpha 1$-antitripsina, que impede a ação proteolítica da enzima em tecidos sadios, acelerando o processo de cicatrização. O objetivo deste trabalho foi utilizar pomadas à base de papaína na cicatrização de uma ferida na falange proximal do membro pélvico direito de um equino, a fim de realizar a remoção de tecido necrótico e promover a aceleração da cicatrização. 0 presente trabalho descreve o uso de papaína creme, nas concentrações de $2 \%$ e 4\%, no tratamento de ferida aberta, lacerada, contaminada e de grau IV no membro pélvico direito de um equino de 15 meses, macho, raça Crioula, 100kg. Havia presença de míiase e um arame enrolado na região da falange proximal do membro pélvico direito. Ao passo, não apoiava o membro no chão. Foi observado rompimento do ligamento extensor digital comum. A ferida foi limpa com líquido de Dakin e iodo degermante. Aplicou-se a pomada à base de nitrofurasona e, em seguida, a região foi envolvida por algodão e atadura. Foi administrado por via intramuscular $5 \mathrm{ml}$ de soro antitetânico. Foi aplicado 10.000UI/kg de penicilina procaína, flunexin meglumine na dose de $1 \mathrm{mg} / \mathrm{kg}$. No quarto dia, a pomada à base de nitrofurasona foi substituída por papaína creme a 4\%, em aplicações diárias, para retirar o tecido necrótico e fibrina presente na ferida. No sétimo dia, iniciou-se a aplicação diária de papaína creme a 2\%, como acelerador do tecido de 
granulação nas áreas sem a presença de fibrina. Do 35 ao 60 dia, o tratamento foi realizado somente com a papaína a $2 \%$, pois não havia mais áreas de necrose presentes na ferida. A partir da utilização da pomada à base de papaína nas concentrações adequadas para a fase da cicatrização em que a ferida se encontrava, aos 70 dias de tratamento a ferida estava cicatrizada, sem tecido de granulação exuberante. 0 equino voltou a apoiar o membro pélvico direito no chão e não apresentava claudicação. 0 valor gasto com as pomadas à base de papaína em todo o tratamento foi de $\mathrm{R} \$ 40$. Ferimentos no aparelho locomotor dos equinos são rotineiros e de difícil prevenção. A cicatrização costuma ser lenta e geralmente ocorre formação excessiva de tecido de granulação. Neste contexto, a cicatrização por segunda intenção se torna um desafio ao médico veterinário. Existem muitas formulações tópicas para este fim, porém muitas são ineficazes e caras. A retirada de tecidos desvitalizados é de fundamental importância na cicatrização de feridas, pois a presença de tecido inviável abriga, aquece e estimula a proliferação de microorganismos que retardam a regeneração do tecido e podem propiciar episódios de artrite infecciosa e até mesmo de sepse. Mesmo que a reparação tecidual seja um processo sistêmico, é muito importante favorecer condições locais a partir de terapias tópicas. A papaína, além de desbridar a ferida, acelerar a limpeza e o processo de cicatrização, promove o alinhamento das fibras que compõem o colágeno, proporcionando o crescimento uniforme e resultando em uma cicatriz mais plana. A papaína surge como um eficiente tratamento e de baixo custo, atuando como desbridante e estimulante do processo de cicatrização de feridas.

Palavras-chave: Carica papaya. Papaína. Cicatrização. 